\title{
Taxonomic notes on Leandra (Melastomataceae, Miconieae)
}

\author{
Marcelo Reginato ${ }^{1,3}$ e Renato Goldenberg ${ }^{2}$
}

Received: 3.11.2011; accepted: 4.04.2012

\begin{abstract}
Taxonomic notes on Leandra (Melastomataceae, Miconieae)). In this paper we propose 11 synonyms and six lectotypes for eastern Brazilian species of Leandra. Leandra urophylla and L. nutans are placed in the synonymy of L. acutiflora; Leandra atropurpurea in the synonymy of L. australis; Ossaea ramboi in the synonymy of L. catharinensis; Leandra pulchra in the synonymy of L. clidemioides; Leandra furfurella in the synonymy of L. cordigera; Leandra macrosepala in the synonymy of L. laevigata; Leandra dusenii in the synonymy of L. microphylla; Leandra dolichodons in the synonymy of L. penduliflora; Leandra dasytricha and L. mosenii in the synonymy of L. variabilis. We also propose lectotypes for L. australis, L. atropurpurea, L. cordigera, L. dusenii, L. laevigata, and L. pulchra.

Key words: Leandra sensu stricto, Lectotypes, Miconia, Ossaea
\end{abstract}

RESUMO - (Notas taxonômicas em Leandra (Melastomataceae, Miconieae)). Neste trabalho são propostos 11 novos sinônimos e seis lectótipos para espécies de Leandra da região leste do Brasil. Leandra urophylla e L. nutans são sinonimizadas sob L. acutiflora; Leandra atropurpurea sob L. australis; Ossaea ramboi sob L. catharinensis; Leandra pulchra sob L. clidemioides; Leandra furfurella sob L. cordigera; Leandra macrosepala sob L. laevigata; Leandra dusenii sob L. microphylla; Leandra dolichodons sob L. penduliflora; Leandra dasytricha e L. mosenii sob L. variabilis. São propostos também lectótipos para L. australis, L. atropurpurea, L. cordigera, L. dusenii, L. laevigata e L. pulchra.

Palavras-chave: Leandra sensu stricto, Lectótipos, Miconia, Ossaea

\section{Introduction}

Leandra Raddi is one of the largest genera in the Melastomataceae, with about 250 accepted species (Melastomataceae.net 2007-2012) in tropical and subtropical America. As currently defined, the genus is polyphyletic, with three unrelated clades: two of them are respectively formed by former sections Tschudya Cogn. and Secundiflorae Cogn., while the third clade is mostly composed of species from the five remaining sections, the genus Pleiochiton A.Gray, and some species of Ossaea DC. and Clidemia D.Don (Martin et al. 2008). This last clade (Leandra sensu stricto, following Goldenberg et al. 2008) includes ca. 75\% of the total Leandra species (including its generotype), and is primarily distributed in the Atlantic Forest region of eastern Brazil. The last complete revision of the genus was published in the $19^{\text {th }}$ century (Cogniaux 1891), and not even a small part of it has been revised since then. Several arrangements have been adopted for treatments in regional floras (Wurdack 1962, 1973, 1980, Wurdack et al. 1993, Camargo et al. 2009, Souza \& Baumgratz 2009), and a lot of revisional work remains to be done.

In this paper, we solve problems related to nomenclature and species limits of eastern Brazilian Leandra based on our own morphological studies, but primarily from discussions by previous works (Wurdack 1962, Camargo et al. 2009) and herbarium notes by John Wurdack. Most of the new synonyms are related to species described for Leandra section Chaetodon Cogn. that have a synonym in one of the other sections. Leandra section Chaetodon is defined by pseudolateral inflorescences (terminal when in bud and flowering and lateral when fruiting). Inflorescence position is one of the two characters traditionally used to circumscribe genera in the tribe Miconieae and great taxonomic importance has historically been placed on this character. Nonetheless, it has been demonstrated to be either prone to miscoding (Judd \& Skean 1991)

1. The New York Botanical Garden, Institute of Systematic Botany, Bronx, 10458 New York, NY, United States

2. Universidade Federal do Paraná, Departamento de Botânica, Centro Politécnico, Caixa Postal 19031, 81531-970 Curitiba, PR, Brazil

3. Corresponding author: reginatobio@yahoo.com.br 
or to be highly homoplastic (Michelangeli et al. 2004, Goldenberg et al. 2008, Martin et al. 2008).

\section{Results and Discussion}

1. Leandra acutiflora (Naudin) Cogn. in Mart., Eichler \& Urban, Fl. Bras. 14(4): 162. $1886 \equiv$ Clidemia acutiflora Naudin, Ann. Sci. Nat., Bot., ser. 3, 17(5): 371. 1851. Type: BRAZIL. RIO DE JANEIRO: "in montibus Serra dos Orgãos", Vauthier 42 (holotype P, isotypes GH! $(\times 2), \mathrm{P}, \mathrm{MPU}, \mathrm{W}$; see Martin \& Cremers 2007).

$=$ Leandra urophylla (Triana) Cogn. in Mart., Eichl. \& Urban, Fl. Bras. 14(4): 184. $1886 \equiv$ Oxymeris urophylla Triana, Trans. Linn. Soc. London 28(1): 94. 1871. syn. nov. Type: BRAZIL. Rio DE JANEIRo: Widgren s.n. (holotype $\mathrm{S}$ - photo!).

$=$ Leandra nutans Cogn. in A.DC. \& C.DC., Monogr. Phan. 7: 676. 1891. syn. nov. Type: BRAZIL. Rio DE JANeiro: Nova Friburgo, Alto Macahé, Glaziou 16915 (holotype BR - photo!, isotypes BR - photo!, F - photo!, K - photo!, NY!, Z - photo!).

Distribution: Endemic to Brazil from Espírito Santo to Santa Catarina States in the Atlantic Forest.

Selected specimens examined: BRAZIL. EspíRITo SAnto: Santa Teresa, 6-V-2003, R.R. Vervloet 2346 (UPCB). Minas Gerais: Rio Preto, 21-I-2006, N.L. Abreu 47 (UPCB). PARANÁ: Piraquara, 8-I-2010, M. Reginato et al. 1081 (UPCB, NY). RIO DE Janeiro: Nova Friburgo, Macaé de Cima, 22-I-2010, M. Reginato et al. 1139 (UPCB, NY). SANTA Catarina: Blumenau, 19-XI-1959, R.M. Klein 2301 (NY). São PAULo: Caraguatatuba, 9-VIII-2000, G.L. Esteves 2699 (NY). UnKNown LOCALITY: W.J. Burchell 3664 (GH).

Cogniaux (1891) placed L. acutiflora in section Oxymeris, but included both L. nutans and L. urophylla in section Chaetodon. The position of the inflorescence was considered diagnostic for these sections (terminal in Oxymeris and transitioning from terminal to lateral in Chaetodon), but this character is highly variable among some species and not always evident on herbarium sheets lacking either flowering or fruiting material. Phylogenetic analyses showed that these sections are not monophyletic as previously discussed (Martin et al. 2008), confirming that this character is homoplastic. The types of $L$. nutans and L. urophylla share with $L$. acutiflora sparse, deciduous, minute dendritic trichomes, and leaves distinctly plinerved bearing white tufted domatia on the axils of the lateral nerves on the abaxial surface. There is some degree of variation in the external calyx teeth, from obscurely tuberculate in the type of $L$. nutans to ca. $1 \mathrm{~mm}$ long in the type of L. urophylla, with intermediate states in the type and also in several specimens currently identified as L. acutiflora. Leandra urophylla has been proposed to be distinguishable by leaves with caudate to acuminate apices, but these features are frequently found within the specimens from the whole complex. The synonymization of $L$. nutans under $L$. urophylla was suggested but not formally published by Wurdack (1962), and recently Baumgratz \& Souza (2011) suggested that $L$. nutans should be treated under L. acutiflora.

2. Leandra australis (Cham.) Cogn. in Mart., Eichler \& Urban, Fl. Bras. 14(4): 104. $1886 \equiv$ Clidemia australis Cham., Linnaea 10: 44. 1836. Type: BRAZIL: "Provincia Cisplatina", Sellow s.n. (lectotype, M! $(\times 2)$ designated here).

$=$ Leandra atropurpurea Cogn. in Mart., Eichler \& Urban, Fl. Bras. 14(4): 106, pl. 23. 1886. syn. nov. Type: BRAZIL: "loco haud indicato", Sellow 159 (lectotype, M! designated here).

Distribution: Forested regions of Argentina, Paraguay and Brazil from São Paulo to Rio Grande do Sul States.

Selected specimens examined:ARGENTINA. MisIONES: Guarani, 25-XI-1993, S.G. Tressens et al. 4747 (GH). BRAZIL. ParanÁ: Antonina, 5-XII-1986, A.C. Cervi 2414 (NY, UPCB). Rio Grande do Sul: São Francisco de Paula, 4-I-2010, M. Reginato 1071 (NY, UPCB). SANTA CATARINA: Brusque, 5-III-1952, L.B. Smith 6042 (NY). São PaUlo: Itapetininga, 29-X-1976, P.E. Gibbs 3284 (NY). PARAGUAY. Misiones: Santiago, 19-XI-1956, T.M. Pedersen 4354 (NY). CAaguazú: Caaguazú, II-1905, E. Hassler $8881 a$ $(\mathrm{NY})$.

Cogniaux (1886) placed both L. australis and L. atropurpurea in the section Niangae, among the group with reduced internal calyx lobes. The diagnostic character was supposed to be a difference in leaf venation: 5-7 basal in L. australis versus 5 suprabasal in L. atropurpurea. Despite the fact that the types agree with this distinction, this species is very common in southern Brazil and adjacent areas, and shows a broad variation in leaf size, nerve number and the distance from the lateral nerves to the base (basal versus suprabasal). These variation is not consistently related to other morphological features 
or geographical range, and do not sustain two distinct species. The synonymization of $L$. atropurpurea under L. australis was suggested by Wurdack (1962).

3. Leandra catharinensis Cogn. in A.DC. \& C.DC., Monogr. Phan. 7: 1188. 1891. Type: BRAZIL. SANTA CATARINA: "Kleiner strauch in der Serra do Oratorio, Araucarienwald", E. Ule 1450 (holotype BR-photo!, isotype US!).

= Ossaea ramboi Brade, Sellowia 8: 378. 1957. syn. nov. Type: BRAZIL. Rio Grande Do Sul: São Francisco de Paula, Itaimbezinho, 20-II-1953, B. Rambo s.n. (holotype PACA, isotypes HB, RB!).

Distribution: Endemic to Brazil, from Paraná to Rio Grande do Sul States in Araucaria Forest.

Selected specimens examined: BRAZIL. PARANÁ: Curitiba, 1-X-2007, R. Goldenberg 922 (NY, UPCB). Santa Catarina: Campo Erê, 7-XII-1964, L.B. Smith 13780 (GH, NY); Urupema, 30-XII-2009, M. Reginato 1050 (NY, UPCB). Rio Grande do Sul: São José dos Ausentes, 2-I-2010, M. Reginato 1062 (NY, UPCB).

Brade (1957) did not provide any comment nor compared $O$. ramboi with any species of Ossaea or Leandra. In a taxonomic review of the Brazilian Ossaea this species was excluded from the treatment and the author suggested it belongs to Leandra, based on inflorescence characters (Souza 1998). Leandra catharinensis was assigned to section Chaetodon by Cogniaux (1891), which is defined by terminal inflorescences (when in bud and flowering) that become lateral (when fruiting). The type specimen of $O$. ramboi has clearly pseudolateral inflorescences and shares all other morphological features with L. catharinensis. This synonymization was previously suggested by Wurdack (1962).

4. Leandra clidemioides (Naudin) Wurdack, Phytologia 55(3): $145.1984 \equiv$ Platycentrum clidemioides Naudin, Ann. Sci. Nat., Bot., ser. 3, 18(2): 114. 1852. Type: FRENCH GUYANA: 1845, Mélinon 85 (holotype P, isotypes P; see Martin \& Cremers 2007).

= Leandra pulchra Cogn. in Mart., Eichler \& Urban, Fl. Bras. 14(4): 163. 1886. syn. nov. Type: BRAZIL: "Brasilia meridionali", Sellow 821 (lectotype, BR photo! designated here, duplicates GH!, K - photo!, US!).

Distribution: Bolivia, Colombia, Ecuador, Peru, Trinidad, Venezuela, Guyana, French Guiana (Wurdack et al. 1993), and Brazil from Bahia to São Paulo States.
Selected specimens examined: BOLIVIA. MAPIRI: San Carlos, 10-I-1927, O. Buchtien 997 (NY). BRAZIL. BAHIA: Santa Cruz de Cabrália, 18-X-1979, S.A. Mori et al. 10794 (NY); Itacaré, 10-VIII-1998, J.G. Jardim 1828 (NY); "inter Victoria et Bahia", Sellow s.n. (K, syntype of L. pulchra). COLOMBIA. Putumayo: Puerto Asís, 6-VIII-1965, R.M. King 6228 (NY). ECUADOR. Zamora-Chinchipe: Paquisha, 13-IV-1985, G. Harling 24099 (NY). FRENCH GUIANA. Regina: Mt. Tortue, 12-VI-1988, C. Feuillet 10104 (NY). TRINIDAD AND TOBAGO. Rox Borough - Parlatuvér road, 25-X-1937, N.Y. Sandwith 1930 (NY). VENEZUELA. Sucre: Peninsula de Paria, 5-III-1966, J.A. Steyermark 85098 (NY).

Leandra clidemioides can readily be recognized by stamens bearing a dorsal, erect appendage (Wurdack et al. 1993). Cogniaux (1886) was probably misled in describing L. pulchra because the type specimens bear only fruits and consequently he did not see stamens. Moreover, he mentioned that Leandra (Platycentrum) clidemioides should occur in French Guyana, Trinidad and in an unknown place in Brazil, being apparently unaware that this species also occurs in eastern Brazil. The types of L. pulchra have the same appressed trichomes on the branches, strongly 5-plinerved leaves, inflorescences with accessory branches and large, light-colored fruits of $L$. clidemioides, indicating that both must be synonymized.

5. Leandra cordigera (Triana) Cogn. in Mart., Eichler \& Urban, Fl. Bras. 14(4): 166. $1886 \equiv$ Oxymeris cordigera Triana, Trans. Linn. Soc. London 28: 94. 1871. Type: BRAZIL: "in Brasilia meridionali", Sellow 4862 (lectotype, US! designated here).

= Leandra furfurella Rechinger, Denkschr. Akad. Wien, Math. Nat. 79: 258, pl. 23, fig.1-4. 1908. syn. nov. Type: BRAZIL. São Paulo: "Prope Campo Grande inter Santos et urbem São Paulo", 750 m, VII-1901, Wettstein \& Schiffner s.n. (not located).

Distribution: Endemic to Brazil from Minas Gerais to Santa Catarina States in the Atlantic Forest.

Selected specimens analyzed: BRAZIL. MinAs Gerais: Alagoa, 9-XI-2007, L. Echternacht 1542 (UPCB). PARANÁ: Piraquara, 16-II-2008, R. Goldenberg 1029 (UPCB, NY). Santa Catarina: São José, 24-X-1957, R. Reitz 5362 (NY, US). São PaUlo: Santo André, 1892, G. Edwall 14361 (NY).

Rechinger (1908) described L. furfurella based on a single collection that has not been located. 
Nevertheless, the publication provides a good picture of the type, along with drawings of one trichome and flower buds. These show exactly the same small stellate-furfuraceous indument, small, cordate leaves, and acute calyx teeth found in L. cordigera. The author did not compare the species to L. cordigera or to any other species in the genus, and was probably unaware of its existence. The holotype of $L$. cordigera was destroyed in Berlin, thus the US isotype was chosen here as the lectotype.

6. Leandra laevigata (Triana) Cogn. in Mart., Eichler \& Urban, Fl. Bras. 14(4): 177. 1886 三 Oxymeris laevigata Triana, Trans. Linn. Soc. Lond. 28: 94. 1871. Type: BRAZIL. Minas Gerais: "In montibus Serra de Mantiqueira", Sellow s.n. (lectotype, US! designated here).

= Leandra macrosepala Ule, Notizbl. Königl. Bot. Gart. Berlin 6: 353. 1915. syn. nov. Type: BRAZIL. Rio de JANeiro: Petrópolis, "In Walde bei $900 \mathrm{~m}$ ", X-1896, Ule 4224 (holotype B - destroyed, photo in $\mathrm{F}$ !).

Distribution: Endemic to Brazil from Bahia to Rio Grande do Sul States in the Atlantic Forest.

Selected specimens examined: BRAZIL. BAHIA: Camacan, 13-II-2005, J.G. Jardim 4437 (UPCB). Minas Gerais: Santa Maria do Salto, 21-II-2005, J.R. Stehmann 3998 (UPCB). ParanÁ: Morretes, 19-XI-1998, G.G. Hatschbach 68824 (UPCB); Tunas do Paraná, 17-X-2005, R. Goldenberg 733 (NY, UPCB). Rio Grande do Sul: São Francisco de Paula, 4-I-2004, M. Reginato 1074 (NY, UPCB). Rıo de JANeIro: Itatiaia, IX-1934, A.C. Brade 14005 (NY). Nova Friburgo, 22-I-2010, M. Reginato et al. 1140 (NY, UPCB). Santa Catarina: Ibirama, 7-III-1956, R.M. Klein 1957 (NY); Vidal Ramos, 15-VI-1957, R. Reitz 4308 (NY). SÃo Paulo: Tapiraí, 19-X-1994, K.D. Barreto 3081 (MBM).

When describing L. macrosepala, Ule (1915) compared it with L. gracilis Cogn. and L. pulchra, mentioning that the long calyx external teeth would be a diagnostic character. The species was not assigned to any section, but the last two belong to Leandra section Oxymeris, while L. laevigata was assigned to Leandra section Chaetodon (Cogniaux 1891). It seems that Ule was misled either by the different sections (see discussion above) or perhaps was unaware of L. laevigata. Both types share the same glabrous and polished leaves and the conspicuous calyx external teeth. This synonymization was previously suggested by J.J. Wurdack on a herbarium note. The holotype of L. laevigata was destroyed in Berlin, thus the US isotype was chosen here as the lectotype.

7. Leandra microphylla Cogn. in A.DC. \& C.DC., Monogr. Phan. 7: 655. 1891. Type: BRAZIL. PARANÁ: Tibagi, "in rupibus ad Rincão das Pedras prope São Bento", Schwacke 2612 (holotype BR photo!).

= Leandra dusenii Cogn., Ark. Bot. 9(15): 9. 1910. syn. nov. Type: BRAZIL. Paraná: Vila Velha, 19-XII-1903. P.K. Dusén 3440a (lectotype, S - photo! designated here).

Distribution: Endemic to the Paraná State, Brazil in rocky fields.

Selected specimens analyzed: BRAZIL. Paraná: Campo Largo, 6-XI-2001, R. Goldenberg 538 (UPCB); Castro, 15-I-1965, L.B. Smith et al. 14492 (NY); Lapa, 31-XI-1967, G.G. Hatschbach 18216 (MBM); Palmeira, 12-XII-1965, R. Reitz 17462 (GH). Piraí do Sul, Serra de Furnas, 31-III-1957, G.G. Hatschbach 3851 (MBM, NY); Ponta Grossa, Vila Velha, 10-III-1904, P.K. Dusén 4102 (S, syntype of L. dusenii); 26-XI-1908, P.K. Dusén 7231 (NY); 21-X-1989, A.C. Cervi 2882 (UPCB); Tibagi, 27-X-2005, R. Goldenberg 818 (UPCB).

Cogniaux did not mention L. microphylla while describing L. dusenii (Wurdack 1970). He also seemed to be misled by placing these two species in different sections (see discussion under L. acutiflora): L. microphylla was placed in the terminal-flowered section Carassanae, while L. dusenii in the terminal/ lateral-flowered section Chaetodon. The inflorescences in both types and recent collections are terminal and scarcely conspicuous due to its reduced size. Cogniaux (1891, 1910) described 5-nerved leaves for L. dusenii, and 3-nerved leaves for L. microphylla, but the types of both show leaves with 3 nerves and a faint submarginal pair that stays between both character states previously mentioned. Apart from these features, the descriptions of both species are very similar. Additionally, both types were collected about $80 \mathrm{~km}$ from each other on grasslands in the Paraná State. Wurdack (1970) had already discussed the differences between these two species, based on fragments of the specimens in BR. According to him, specimens of L. microphylla should have a sparsely setulose torus, glabrous style and slightly longer stamens, while $L$. dusenii should have a glabrous torus, sparsely strigulose style and plump anthers. Wurdack (1970) mentioned some intermediate specimens that he hesitate to assign to one of these species, and concluded that he was not 
sure if these species were distinct. Following the same line, and based on the analysis of several specimens, Camargo et al. (2009) concluded that there was only a single species and they mentioned only L. microphylla in their treatment of Leandra in Paraná State.

8. Leandra penduliflora (Naudin) Cogn. in Mart., Eichler \& Urban, Fl. Bras. 14(4): 176. $1886 \equiv$ Clidemia pendulifora Naudin, Ann. Sci. Nat., Bot., ser.3, 17(5):369.1851.Type:BRAZIL. Minas GeraIs: Cachoeira do Campo, 1843, Claussen 139 (holotype $\mathrm{P}$, isotype BR - photo! $\times 2$ ).

$=$ Leandra dolichodons Cogn. in Mart., Eichler \& Urban, Fl. Bras. 14(4): 176, pl. 37, fig. 2. 1886. syn. nov. Type: BRAZIL. Minas Gerais: "Serra da Carassa", Sellow 1297 (holotype BR - photo!, isotypes K - photo!, US!).

Distribution: Endemic to Minas Gerais State, Brazil in rocky fields.

Selected specimens examined: BRAZIL. MinAs GERAIS: Serra do Caraça, 25-I-1971, H.S. Irwin et al. 29074 (NY, US); Serra do Caraça, 26-I-1971, H.S. Irwin et al. 29218 (F, NY, US), Serra do Caraça, 5-IV-1885, E.A. Vainio s.n. (US2368154).

Cogniaux (1886) placed both species in section Chaetodon and they appear together in the identification key. According to the key, L. penduliflora should have branched shoots, obovate-oblong leaves and external calyx teeth as long as half the hypanthium length, while $L$. dolichodons should have simple, unbranched shoots, wide obovate leaves and external calyx teeth slightly shorter than the hypanthium length. Despite the fact that the types agree with this distinction, this species shows variation in leaf and external calyx teeth size, the last ranging from 0.9 to $1.5 \mathrm{~mm}$ long, which is equivalent to 35 to $85 \%$ of the hypanthium length. Moreover, the type localities are both situated in the "Quadrilátero Ferrífero" region of Minas Gerais state. Therefore, L. penduliflora might be identified by its glabrous (sometimes with trichomes restricted to the nerves on abaxial side), coriaceous leaves, with a conspicuous revolute margin, cuneate base, and slightly plinerved veins, the pseudolateral, glabrous inflorescence, and a hypanthium with a torus bearing dense indument.

9. Leandra variabilis Raddi, Melast. Bras.: 42, tab. 5, fig. 2. 1828. Type: BRAZIL. Rio DE JANEIRO: "Ritrovata nei possessi del Console generale di Russia a Rio-Janeiro Sig. Cav. de Langsdorff, luogo detto, la Mandiocca, presso le montagne d'Estrella", Raddi s.n. (holotype PI!, isotypes FI!, PI!).
$=$ Leandra dasytricha (A.Gray) Cogn. in Mart., Eichler \& Urban, Fl. Bras. 14(4): 113. $1886 \equiv$ Clidemia dasytricha A. Gray, U.S. Expl. Exped., Phan. 1: 588. 1854. syn. nov. Type: BRAZIL. Rio DE JANEIRO: Wilkes s.n. (holotype GH!).

$=$ Leandra mosenii Cogn. in Mart., Eichler \& Urban, Fl. Bras. 14(4): 114: pl. 26. 1886. syn. nov. Type: BRAZIL. São Paulo: "Habitat in sylvis caeduis ad Sorocaba prope Santos", Mosen 2857 (holotype S photo!).

Distribution: Endemic to Brazil from Bahia to Rio Grande do Sul States in the Atlantic Forest.

Selected specimens examined: BRAZIL. BAHIA: São José da Vitória, 27-VI-2000, A.M. Amorim 3545 (NY). Espírito SAnto: Nova Lombardia, 7-II-2011, M. Reginato et al. 1202 (NY, UPCB). Minas Gerais: Almenara, 22-II-2003, J.A. Lombardi 5157 (UPCB). Paraná: Campina Grande do Sul, 17-X-2005, R. Goldenberg 709 (NY, UPCB). Rio de JANEIRo: Teresópolis, P.N. da Serra dos Órgãos, 18-I-2010, M. Reginato et al. 1098 (NY, UPCB). Rio GRANDE Do Sul: São Leopoldo, 7-XII-1948, B. Rambo 38548 (NY). Santa Catarina: Ibirama, 15-VI-1956, R.M. Klein 2113 (M, NY). SÃo Paulo: Ubatuba, 17-XII-1979, W. Benson 10850 (NY). UnKNown LOCALITY: Burchell 3597 (GH).

The name $L$. variabilis has been rarely applied, and almost all the available specimens of this species are currently filed under $L$. dasytricha. Apparently, Naudin (1852) and Triana (1871) were unaware of Raddi's species, since it was not included in their monographs. Cogniaux (1886) recognized both $L$. variabilis and $L$. dasytricha, and used the 4 -sulcate branches to segregate $L$. dasytricha and L. mosenii from the others. Nonetheless, Cogniaux probably did not examine the type of $L$. variabilis, since the single collection cited is Gardner 223 (from Serra dos Órgãos). Wurdack (1962) mentioned that L. variabilis and $L$. dasytricha were closely related, the former differentiated by the finely roughened trichomes (more robust in $L$. dasytricha). He also suggested that $L$. mosenii was a likely synonym of $L$. dasytricha. Apart from the trichome plasticity, the specimens also show variation in leaf shape and size and inflorescence position, and should be treated as a single taxon. Therefore, among the species of section Carassanae (with dense indument and dendritic trichomes), L. variabilis might be readily identified by the small flowers with short, white anthers (bigger and pink in L. carassana and yellow in L. regnellii). 


\section{Acknowledgments}

We would like to thank Fernando Straube for insight on the exact type locality of L. microphylla, to Karin dos Santos and Mia Ehn for the images of the types from $\mathrm{S}$ and to V.P. Doyle for reviewing the manuscript. $R G$ received a research productivity grant from CNPq and MR is supported by the PBI Miconieae grant to F.A. Michelangeli (NSFDEB-0818399).

\section{Literature cited}

Baumgratz, J.F.A. \& Souza, M.L.D.R. 2011. Melastomataceae na Reserva Ecológica de Macaé de Cima, Nova Friburgo, Rio de Janeiro, Brasil. II - Leandra (Miconieae). Rodriguésia 62: 629-662.

Brade, A.C. 1957. Melastomatáceas novas do Estado do Rio Grande do Sul. Sellowia 8: 367-394.

Camargo, E.A., Souza, C.M.F., Caddah, M.K. \& Goldenberg, R. 2009. O gênero Leandra, seções Carassanae, Chaetodon, Niangae, Oxymeris e Secundiflorae (Melastomataceae) no Paraná. Rodriguésia 60: 595-631.

Cogniaux, A. 1886. Melastomataceae. In: C.F.P. Martius, A.G. Eichler \& I. Urban (eds.). Flora Brasiliensis. Frid. Fleischer, Lipsiae, v.14, pars 3, 4, pp. 1-510.

Cogniaux, A. 1891. Melastomataceae. In: A. De Candolle \& C. De Candolle (eds.). Monographiae Phanerogamarum. G. Masson, Paris, v.7, pp. 1-1256.

Cogniaux, A. 1910. Melastomataceae. In: P.K. Dusén (ed.). Gefässpflanzen aus Paraná (Südbrasilien). Arkiv för Botanik 9: 1-37.

Goldenberg, R., Penneys, D.S., Almeda, F., Judd, W.S. \& Michelangeli, F.A. 2008. Phylogeny of Miconia (Melastomataceae): patterns of stamen diversification in a megadiverse neotropical genus. International Journal of Plant Sciences 24: 315-327.

Judd, W.S. \& Skean, J.D. 1991. Taxonomic studies in the Miconieae (Melastomataceae). IV. Generic realignments among terminal-flowered taxa. Bulletin of the Florida Museum of Natural History, Biological Sciences 36: $25-84$.

Martin, C.V. \& Cremers, G. 2007. Les Melastomataceae américaines décrites par C. Naudin. Le Journal de Botanique de la Société de botanique de France 37: 3-111.
Martin, C.V., Little, D.P., Goldenberg, R.\& Michelangeli, F.A. 2008. A phylogenetic evaluation of Leandra (Miconieae, Melastomataceae): a polyphyletic genus where the seeds tell the story, not the petals. Cladistics 24: 315-327.

Melastomataceae.net. 2007-2012. Melastomataceae. net, a site with information on the biodiversity of Melastomataceae. http://www.melastomataceae.net (accessed in Marchr 20 $0^{\text {th }}, 2012$ ).

Michelangeli, F.A., Penneys, D.S., Giza, J., Soltis, D., Hils, M.H. \& Skean, J.D. 2004. A preliminary phylogeny of the tribe Miconieae (Melastomataceae) based on nrITS sequence data and its implications on inflorescence position. Taxon 53: 279-290.

Naudin, C. 1852. Melastomacearum monographicae descriptionis. Annales des Sciences Naturelles, Botanique, Series 3, 18: 86-154.

Rechinger, C. 1908. Melastomataceae. In: R. von Wettstein \& V. Schiffner (eds.). Ergebnisse der botanischen Expedition der kaiserlichen Akademie der Denkschriften der Kaiserlichen Akademie der Wissenschaften, Wien. Mathematisch-Naturwissenschaftliche Klasse, Vienna, v.79, pp. 246-264.

Souza, M.L.D.R. 1998. Revisão taxonômica do gênero Ossaea DC. (Melastomataceae) no Brasil. Tese de Doutorado, Universidade de São Paulo, São Paulo.

Souza, M.L.D.R. \& Baumgratz, J.F.A. 2009. Melastomataceae: Leandra Raddi. In: M.G.L. Wanderley, G.J. Shepherd, T.S. Melhem, A.M. Giulietti \& S.E. Martins (eds.). Flora fanerogâmica do Estado de São Paulo. Impressa Oficial, São Paulo, v.6, pp. 32-68.

Triana, J. 1871. Les Mélastomacées. Transactions of the Linnean Society of London 28: 1-188.

Ule. E. 1915. Melastomataceae. In: R. Pilger (ed.). Plantae Uleanae novae vel minus cognitae. Notizblatt des Königlichen botanischen Gartens und Museums zu Berlin 60: 348-368.

Wurdack, J.J. 1962. Melastomataceae of Santa Catarina. Sellowia 14: 109-207.

Wurdack, J.J. 1970. Certamen Melastomataceis XV. Phytologia 20: 369-389.

Wurdack, J.J. 1973. Melastomataceae. In: T. Lasser (ed.) Flora de Venezuela. Instituto Botánico, Caracas, v.8, pp. 1-819.

Wurdack, J.J. 1980. Melastomataceae. In: G. Harling \& B. Sparre (eds.). Flora of Ecuador. University of Göteborg, Göteborg, v.13, pp. 1-406.

Wurdack, J.J., Morley, T. \& Renner, S.S. 1993. Melastomataceae. In: A.R.A.G. van Rijn (ed.). Flora of the Guianas. Koeltz, Koenigstein, v.99, pp. 1-427. 